Vol. 4, No. 1, 2021

\author{
D. S. Katruk, A. S. Masyuk, V. Ye. Levytskyi \\ Lviv Polytechnic National University, \\ Department of Chemical Technology of Plastics \\ SamoiliukD@gmail.com
}

\title{
INFLUENCE OF POLYSTYRENE MODIFIER ON FEATURES OF POLYVINYLCHLORIDE PLASTICS PRODUCTION
}

https://doi.org/10.23939/ctas2021.01.166

The main methods of physical modification of PVC materials is the combination with other polymers, including PS plastic, and the creation of polymer (nano) composites containing metal and silicate fillers. Modification of polyvinyl chloride by polystyrene plastic leads to obtain materials with reduced degree of plasticizer release out of matter volume, adjustable elastic-plastic characteristics, and enhanced physico - mechanical and thermal properties. Physical modification of vinyl chloride polymers by other polymers or nanoscale particles of inorganic nature enables predictable affect on the morphology of these materials and directed regulate their technological and performance properties.

Key words: polyvinyl chloride composites; migration; plasticization; modification; polystyrene; ABS plastic.

\section{Introduction}

PVC materials due to the unique properties have been widely used in various industries. However, in many cases, a wider use of material limited by deficiencies of PVC: low resistance to shock loads, especially in sub-zero temperatures, creep under long-term constant load, high melt viscosity of not plasticized compositions, not enough forming, plasticizer release of material in the process of and so on $[1,2]$.

Some disadvantages can be eliminated by modification of PVC [3], the structural and mechanical modifications, polymer analogous transformations of macro chain, orientation and crystallization, leading to the anisotropy of mechanical properties, the combination of PVC during processing with specific applications, often with polymers, creating composites with nanoscale fillers [4].

Selecting a second component, PVC materials can provide high physical and mechanical properties, increased affinity for the components of the composition, high flexibility and elasticity, high impact strength, high elastic-plastic properties. Combination of polyvinyl chloride with modifiers of the course of processing is the most common. Modifiers are injected into the composition structure by replacing some PVC, and their presence does not cause significant changes necessary qualitative and quantitative composition of the stabilizing system.

The most common is modification of polyvinyl chloride using other polymers [5]. The properties of the final material depends on many parameters such as the nature of the polymer modifier, polymer modifier content, particle size and their morphology, morphological stability.

Copolymers of butadiene with methyl acrylate, facilitate the processing of hard PVC, including vacuum forming, and also increase the impact strength of materials. They reduce the melting of the polymer, lower melt viscosity, prevent rupture of the mass flow in the melt during extrusion, and improve uniformity and quality of its surface. These modifiers can be used in plasticized compositions to improve the manufacturability of the process and the quality of the material. They are usually added in an amount of $3-10 \%$ (by weight), and when adding up to $40 \%$ to the PVC they do not affect the thermal and light stability.

Use as a modifier ABS provides elasticity, toughness and fracture strength. The higher molecular weight of PVC means less modifier need to achieve the same strength [6]. When the content of ABS 


\section{Influence of polystyrene modifier on features of polyvinylchloride plastics production}

copolymer between 7 and $17 \%$ achieved increase of tough sharpness by Sharp notched [7]. Impact strength of PVC compositions with content in it $7 \%$ of modifier is $3.25 \mathrm{~kJ} / \mathrm{m}^{2}$, as the number of modifier increases to $10 \%$ it is $4 \mathrm{~kJ} / \mathrm{m}^{2}$, while $17 \%$ increases it to $5 \mathrm{~kJ} / \mathrm{m}^{2}$. This can be explained by the fact that with increasing concentration of the modifier increases the number of its particles in the mixture increases the probability of collision with crack and impact resistance increases. Also time of melting of the composition depends from the content of the ABS copolymer. With an increasing of ABScopolymer time of melting is sharply reduced. It is $65{ }^{\circ} \mathrm{C}$ with $5 \%$ modifier, $43{ }^{\circ} \mathrm{C}$ with $10 \%$ modifier, $25{ }^{\circ} \mathrm{C}-15 \%$. Reduction of the melting time is negligible with $17 \%$ of modifier is $23{ }^{\circ} \mathrm{C}$.

ABS plastic enhances the performance of the heat warping, resistance to aggressive environment, migration, extraction of modified PVC. Significant effect on the thermal stability can be achieved if some of styrene in SAN replaced by alphamethylstyrene. Mixtures of PVC with ABS are also used for weather-resistant outer layer profiles [8].

Copolymer of styrene and acrylonitrile, especially butadiene-styrene block copolymers with central polybutadiene unit and different styrene content also significantly increase resistance to shock loads PVC. Copolymer of acrylonitrile, butadiene and styrene are well combined with PVC and increase impact strength of PVC material. The higher molecular weight PVC, the less you need a modifier to achieve the same shock strength. Commonly used mixture is from 95 to $75 \%$ (by weight) of PVC and from 5-25\% (by weight) of ABS. The disadvantage of ABS is low efficiency improvement of fluidity of the composition and the shock strength at low temperatures and reduces thermal and light stability of PVC material [9].

To ensure the desired impact modifier important factor is a good cohesion between the components. Satisfactory cohesion can be achieved by the use of additives that increase compatibility, or by introducing specially prepared particle of modifier. Previously dissolving thermoplastic addition in plasticizers can achieve uniform distribution of the modifier in the volume of PVC.

One of the functions of modifiers is also facilitating the processing of PVC blends [10]. They are used to adjust the strength of the polymer melt, promote and enhance the cohesion and homogenization of the melt during its flow in the molding tool, reduce tension in the melt. At the beginning of melting modifier processing ensures the transfer of shear stress in the melt and contributes to the destruction of primary particles of PVC. When PVC begins to melt during processing, long chains of modifiers bind shorter chains of PVC thereby strengthening the melt passes. Modifiers processing also increase the friction between the PVC melt and metal surfaces, resulting in energy absorption.

\section{Materials and methods of research}

Materials based on Lacovyl PB1156 PVC were used for research (TU U 24.1-33129683-004: 2011). Diesterphthalate plasticizers, in particular dibutyl phthalate (DBP), di (2-ethylhexyl) phthalate (DEHP) and diisononyl phthalate (DINF), were used as plasticizers. Polystyrene and ABS plastic were used as a polymer modifier [11].

For the manufacture of test samples, the polymer modifier was dissolved in a plasticizer and mixed with fine PVC in a drum mixer type MSHL-1 for 30-40 min. The resulting composition was subjected to gelation at $363 \mathrm{~K}$ for $1 \mathrm{~h}$ and rolled or granulated using an extruder type Cellier according to the following technological parameters: cylinder temperature $110-140{ }^{\circ} \mathrm{C}$; head temperature $145-155^{\circ} \mathrm{C}$; auger speed $12-20 \mathrm{rpm}$.

The study of elastic-plastic properties was performed on 5 samples, which were plates with a smooth surface with a width of not less than $15 \mathrm{~mm}$ and a thickness of not less than $5 \mathrm{~mm}$, on the device TSHR-76 according to ISO7619.

Vicat softening point of the investigated materials was determined in accordance with ISO 306: 2013 B, the loading was $50 \mathrm{~N}$.

The surface hardness of the conical fluidity point was determined applying Hepler Consistometer at $293 \mathrm{~K}$ by indentation of the steel zone in the polymer sample with a sharpening angle of $58^{\circ} 08^{\prime}$ under a load of $50 \mathrm{~N}$ for $60 \mathrm{~s}$.

\section{Research results and their discussion}

During PVC plasticization by plasticizers of different nature, in particular diesters of phthaletic acid, the phenomena connected with components compatibility play the key role [12]. The introduction of polystyrene modifier preliminary dissolved in the plasticizer increases PVC wetting by the plasticizer 


\section{S. Katruk, A. S. Masyuk, V. Ye. Levytskyi}

and improves the components compatibility (Fig. 1) and technological effectiveness of compositions preparation. The wetting value increases in the row of plasticizers as following: DBP-DINP-DEHP.

While using the plasticizers mixture the wetting angle is averaged [13]. The introduction of polymeric modifier in the amount of $2 \mathrm{wt} \%$ decreases the wetting angle regardless of plasticizer nature. In other words, the wetting of PVC surface increases what is connected with the thermo-dynamic properties changing due to the molecular interaction.

For the plasticizers of linear structure: DBP and DEHP the extreme dependence of wetting angle on PS content is observed with the minimum values at $1.5-3 \mathrm{wt} \%$ and at $4-6 \mathrm{wt} \%$.

The character of PS effect on the angle of PVC surface wetting by the mixture of DBP and DINP plasticizers is different: it decreases with the increase of polymer content. The reason is the increase of components compatibility in such systems.

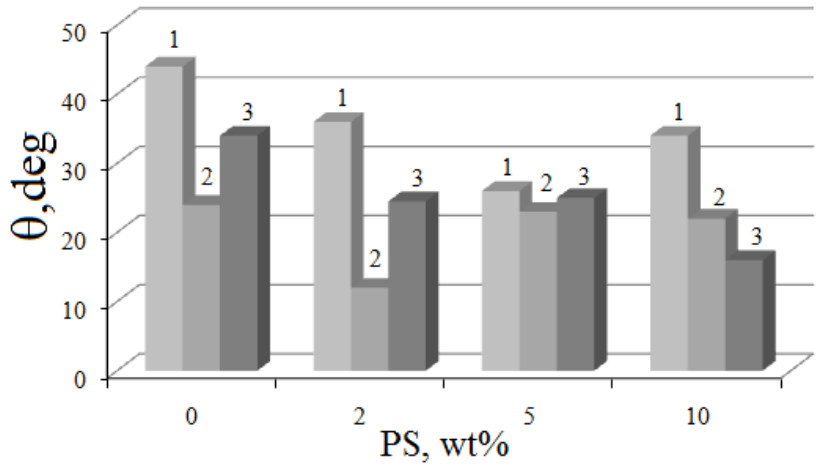

Fig. 1. Effect of PS suspension on the angle of PVC surface wetting by plasticizers:

$1-D B P ; 2-D E H P ; 3-D B P: D I N P=1: 1$

At the same time while using ABS plastic the wetting angle increases with the increase of modifier content (for mixture DBP+DINP, Fig. 2).

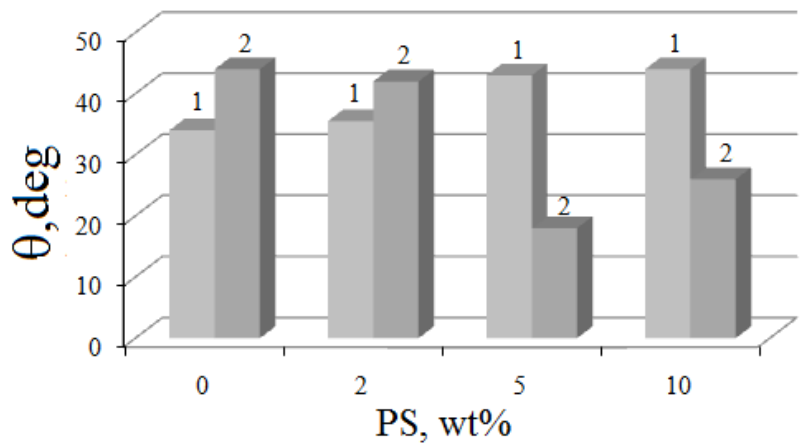

Fig. 2. Effect of ABS plastic on the angle of PVC surface wetting by plasticizers: $1-D B P: D I N P=1: 1,2-D B P$
The increase of ABS content in DBP has the similar effect observed while using PS - the extreme dependence with the minimum values at 4-6 wt \% of polymer. It means that while DBP using the effect of polymeric modifier on the components compatibility is of the same type irrespective of modifier nature.

The effect of polymeric modifier nature and amount on the adhesion was investigated using different plasticizers (Fig. 3).

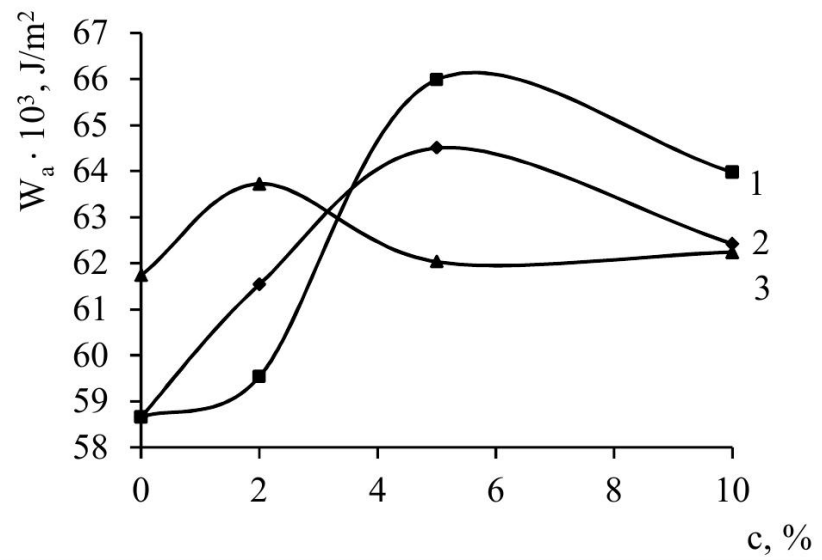

Fig. 3. Effect of polymer-modifier content on the adhesion between PVC-plasticizer: 1,2-DBP; 3 - DEHP; 1,3-PS; 2 - ABS

Regardless of the modifier nature the maximum adhesion is observed at modifier amount of $5 \mathrm{wt} \%$ while using DBP. In the case of DEHP these values are less $(2 \mathrm{wt} \%)$. The compositions with DBP have higher values of adhesion.

The peculiarities of PVC surface wetting by investigated plasticizers indicate the essential effect of polymeric modifier on PVC and plasticizer compatibility; probably they are connected with the change of thermodynamic characteristics leading to the change of molecular interaction between the components, first of all with the participation of macromolecules.

The quantitative estimation of polymercontaining ternary system is based on the assumption that macromolecules packing may be the reason of their mutual repulsion. At the same time the polymeric mixture viscosity is lower than values of pure components calculated in accordance with additive rule. If there is an interaction between polymers, the macromolecule associates of both types are formed and viscosity increases. The data on viscosities were quantitatively interpreted in accordance to the model. The estimation of interaction between different macromolecules was carried out on the basis of 


\section{Influence of polystyrene modifier on features of polyvinylchloride plastics production}

comparison between parameters of molecular interaction determined from experimental data on viscosities $\left(\mathrm{b}_{12}\right.$ exp $)$ and theoretically calculated data $\left(b^{*}{ }_{12}\right.$ theor $)$. The theoretical parameter was calculated according to the formulas:

$$
b_{12}^{*}=\left(b_{11} b_{22}\right)^{112} \text {, }
$$

where

$$
\begin{aligned}
& b_{11}=K_{x 1}\left[\eta_{1}\right]^{2}, \\
& b_{22}=K_{x 2}\left[\eta_{2}\right]^{2} .
\end{aligned}
$$

The experimental parameter $b_{12}$ exp was calculated according to the equation:

$$
\begin{gathered}
\eta_{\text {spec.blend }}=[\eta]_{1} C_{1}+[\eta]_{2} C_{2}+b_{11} C_{1}^{2}+ \\
+2_{b 12 \exp } C_{1} C_{2}+b_{22} C_{2}^{2},
\end{gathered}
$$

where $[\eta]_{1}$ and $[\eta]_{2}-$ characteristic viscosities of the individual polymers; $C_{1}$ and $C_{2}$ - concentrations of first and second polymers in the mixed solution. Defined in this manner the value:

$$
\Delta b_{12}=b_{12 \exp }-b_{12 \text { theor }}^{*}
$$

Thus $\Delta b_{12}$ allows to consider the prior interaction between dissimilar macromolecules, i.e. the presence of mixed associates in the solution (positive value) or between similar ones, i.e. the presence of homoassociates (negative value).

Table 1 represents the dependence of $\Delta b$

\begin{tabular}{|c|c|c|c|c|c|c|c|}
\hline \multirow{3}{*}{$\begin{array}{c}\text { Cpol } \\
\text { g/100 ml }\end{array}$} & \multicolumn{7}{|c|}{ PVC:PS (w/w) ratio } \\
\hline & \multicolumn{6}{|c|}{ DEHP } & DBP \\
\hline & $0.95: 0.05$ & $0.90: 0.10$ & $0.80: 0.20$ & $0.50: 0.50$ & $0.20: 0.80$ & $0.05: 0.95$ & $0.80: 0.20$ \\
\hline 0.4 & 8.1 & 2.4 & -1.0 & -0.5 & 0.2 & -3 & -1.9 \\
\hline 0.6 & 2.2 & 1.9 & -0.8 & -0.3 & -1.5 & -5.5 & -1.0 \\
\hline 0.8 & 2.0 & 0.3 & -0.3 & -0.2 & -1.7 & -5.2 & -0.5 \\
\hline 1.0 & 1.1 & 0.1 & -0.2 & -0.1 & -1.7 & -4.6 & -0.2 \\
\hline 1.2 & -0.5 & 0.1 & -0.1 & $\mathbf{0}$ & -1.6 & -4.1 & -0.1 \\
\hline
\end{tabular}
parameter on polymer concentration in the solution, their ratio and plasticizer nature.

Table 1

\section{Dependence of compatibility parameter $\Delta \mathrm{b}$ on polymer concentrations in the solution and plasticizer nature}

It should be noted that the most essential interactions in PVC-PS-plasticizer system are observed at polymer low concentrations in the plasticizer solution and at the small amount of one polymer relative to another. In the compositions with PVC content $90-95 \%$ the values $\Delta \mathrm{b}$ are positive. This fact testifies to the attraction between dissimilar macromolecules of PVC and PS and existence of mixed associates and hence, to greater compatibility between system components. At the same time the nature of diesterphthalate plasticizer have minor effect on PVC and PS compatibility in the solution.

During PVC plasticizing by diesters of phthalic acid, namely DBP and DEHP, the phenomena connected with thermodynamic compatibility play the key role. In this work the compatibility is characterized by wetting of PVC surface by plasticizers and compatibility parameter. These factors considerably affect the release (migration) of plasticizer from polyvinyl chloride plasticates during exploitation of wares on their basis and so, on their properties.

We studied kinetic regularities of plasticizer release depending on its nature and nature of polymer-modifier (Fig. 4).

The introduction of polymeric modifier into PVC plasticate decreases the plasticizer migration, especially for more elastic materials.

The lowest values of migration degree are observed for DINP and the highest ones - for DBP. Obviously it is connected with the molecular weight of plasticizer and its affinity with PVC. At the same time the increase of plasticizer content in PVC increases the migration degree. The effect of polymer-modifier on migration degree of plasticizer is observed most of all at high values of plasticizer content.

From the standpoint of PVC plasticates use the physic-mechanical properties, especially elasticplastic and thermo-physical ones, are important factors, together with technological characteristics. 


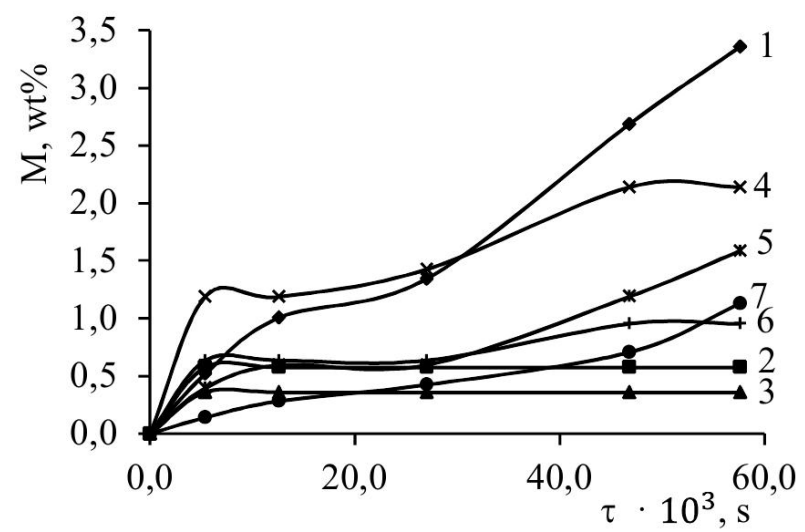

Fig. 4. Kinetics of plasticizer release from PVC materials depending on plasticizer nature:

1,5,6 - DBP; 2,7 - DEHP, 3 -DINP, 4 - DBP:DINP $(w / w)=1: 1$ and polymeric modifier: $5-A B S ; 6,7-P S$.

Plasticizer content is $23 \%$, modifier content is $2.1 \%$

The highest value of hardness $(95.5 \%)$ is observed for PVC plasticates based on DINP (Table 2).
Obviously it is connected with specific interactions between components and their effect on composite morphology. While using DBP and DINP the hardness essentially decreases (49.6\%) but elasticity is almost the same.

It should be noted that elasticity of PVC materials increases with the increase of modifier content. The hardness increases as well. It is observed most of all at high content of plasticizer. Thus, for the compositions based on DBP the increase of PS content by 1.5 times increases the hardness from 13.08 to $19.60 \mathrm{MPa}$ and elasticity from 48.3 to $84.6 \%$. The same regularity is observed while using ABS plastic as the modifier.

The increase of modifier content allows to support elastic properties of PVC plasticates at high level (elasticity is $80-84 \%$ ) even at the considerable (by 4 times) increase of plasticizer content.

Effect of plasticizer and modifier nature on strength properties of PVC

Table 2

\begin{tabular}{|c|c|c|c|c|c|c|c|c|c|}
\hline \multicolumn{6}{|c|}{ Composition, wt parts } & \multicolumn{3}{|c|}{ Elastic-plastic properties } & \multirow{3}{*}{$\begin{array}{c}\text { Vicat } \\
\text { softening } \\
\text { point, }{ }^{\circ} \mathrm{C}\end{array}$} \\
\hline \multirow{2}{*}{ PVC } & \multicolumn{3}{|c|}{ Plasticizer } & \multicolumn{2}{|c|}{ Polymer } & \multirow{2}{*}{ Hardness H, MPa } & \multirow{2}{*}{ Elasticity S, \% } & \multirow{2}{*}{ Plasticity P, \% } & \\
\hline & DBP & DEHP & DINP & PS & ABS & & & & \\
\hline 100 & 30 & - & - & - & - & 7.14 & 42.53 & 57.47 & $\sim 22$ \\
\hline 100 & - & 30 & - & - & - & 62.19 & 40.57 & 59.43 & 40 \\
\hline 100 & - & - & 30 & - & - & 95.57 & 68.40 & 31.60 & 52 \\
\hline 100 & 15 & - & 15 & - & - & 93.52 & 49.60 & 50.40 & 40 \\
\hline 100 & 30 & - & - & - & 2.8 & 22.22 & 52.49 & 47.51 & 36 \\
\hline 100 & 30 & - & - & 2.8 & - & 13.08 & 48.32 & 51.68 & 35 \\
\hline 100 & 30 & - & - & 4.2 & - & 19.60 & 84.61 & 15.39 & - \\
\hline 100 & 90 & - & - & 13.4 & - & 6.29 & 80.14 & 19.86 & - \\
\hline 100 & 120 & - & - & 17.6 & - & 4.60 & 81.29 & 18.71 & - \\
\hline 100 & - & 30 & - & 2.8 & - & 101.15 & 59.00 & 41.00 & 38 \\
\hline
\end{tabular}

Such peculiarities of elastic-plastic properties of modified PVC are connected with reduction of plasticizer molecules mobility under the influence of polymeric modifier and formation of dense fluctuating network in the presence of polystyrene macromolecules. At the same time the nature of plasticizer and polymeric modifier also affects the thermo-physical properties of PVC plasticates which are estimated by thermal stability by Vick. The increase of thermal stability is observed while using plasticizers in the row DBP-DEHP-DINP. The DBP+DINP mix averages the thermal stability values. Polystyrene modifier increases thermal stability of PVC plasticates based on DBP by $15-20^{\circ} \mathrm{C}$.
The presence of the polymer modifier increases the plasticizer wettability polyvinyl chloride, which in turn improves compatibility. Introduction to thermoplastic mixture can reduce the extent of migration.

\section{Conclusions}

Shown technological and physicochemical regularities of obtaining modified polyvinyl chloride polystyrene metal containing composites. Methods of modification of PVC materials are the combination with other polymers, including PS plastic, and the creation of polymer (nano)composites containing metal and silicate fillers. Modification of polyvinyl 


\section{Influence of polystyrene modifier on features of polyvinylchloride plastics production}

chloride by polystyrene plastic leads to obtain materials with reduced degree of plasticizer release out of matter volume, adjustable elastic-plastic characteristics, enhanced physico - mechanical and thermal properties. For the modification of PVC materials should be used nanoscale metal and silicate modifiers that were pretreated by macromolecular surfactants. Effective methods of obtaining nanoscale modifiers are deposition of metal silicates, thermolysis and recovery of metal compounds. These materials can be used in medicine, engineering and other industries.

\section{References}

1. Patrick, S. G. (2005). Practical guide to polyvinyl chloride. UK: Rapra Technology Limited.

2. Sheng K., Adl M., Wang H. and Qian X. (2012). Polyvinyl Chloride Composites. Wiley Encyclopedia of Composites.

3. Yiu-Wing Mai, Zhong-Zhen Yu (2006). Polymer Nanocomposites. Boca Raton: Woodhead Publishing.

4. Levyts'kyi, V., Masyuk, A., Bialopiotrowicz, T., Bilyi, L., and Humenets'kyi T. (2018). Morphology and properties of thermoplastic composites with modified silicate fillers. Materials Science, 54, 48-54.

5. Kelly, A. (2005). Concise Encyclopedia of Composite Materials.NY: Pergamon Press.
6. Mynsker, K. S. (1979). Destruktsyia i stabilizaciya polyvinilchlorida. M.: Chemistry.

7. Rymar, T. E., Ananiev, B. V. (2011). Impact strength modifiers for polyvinyl chloride. Bulletin of the SNU. W. Dalia, 15, 114-117.

8. Wilkers, C. E. (2005). PVC Handbook, Munich: Carl Hanser Verlag.

9. Belhaneche N., Abdelmalik B. (2001). Study of the properties of PVC/ABS blends. Macromol. Symp, 176, $145-154$.

10. Agassant Jean-François, Avenas Pierre, Carreau Pierre J., Vergnes Bruno, Vincent Michel (2017). Polymer Processing Principles and Modellin. Munich: Hanser.

11. Levytskyi, V. E., Laruk Y. V. (2014). Pat. 94849. Ukraine, Lviv Polytechnic National University.

12. Laruk, Yu. V., Levytskyi, V. Ye. (2013). Influence of the nature of the thermoplastic modifier on the migration of the plasticizer from polyvinyl chloride plastics. Bulletin of Lviv Polytechnic National University, "Chemistry, technology and application of substances”, 761, 421-426.

13. Laruk, Yu. V., Levytskyi V. Ye. (2014). Influence of the nature of plasticizer and polystyrene modifier on the properties of polyvinyl chloride plastics and composites. Eastern European Journal of Advanced Technologies, 6/11, 72, 4-8.

Д. С. Катрук, А. С. Масюк, В. С. Левицький

Національний університет “Львівська політехніка", кафедра хімічної технології переробки пластмас

SamoiliukD@gmail.com

\section{ВПЛИВ ПОЛІСТИРОЛЬНОГО МОДИФІКАТОРА НА ОСОБЛИВОСТІ ОДЕРЖАННЯ ПОЛІВІНІЛХЛОРИДНИХ ПЛАСТИКАТІВ}

Основними методами фізичного модифікування ПВХ матеріалів є їх суміщення з іншими полімерами, зокрема полістирольними пластиками, і створення полімерних (нано) композитів, що містять металеві та силікатні наповнювачі. Модифікування полівінілхлориду полістирольним пластиком приводить до отримання матеріалів зі зниженим ступенем вивільнення пластифікатора, регульованими пружно-пластичними характеристиками та підвищеними фізико-механічними і термічними властивостями. Фізичне модифікування вінілхлоридних полімерів іншими полімерами або нанорозмірними частинками неорганічної природи уможливлює передбачуваний вплив на морфологію цих матеріалів та регулювання їхніх технологічних і експлуатаційних властивостей.

Ключові слова: полівінілхлоридні композити; міграція; пластифікування; модифікування; полістирол; АБС-пластик. 